\title{
EFEKTIVITAS PENERAPAN PASAL 7 UNDANG-UNDANG PERKAWINAN NOMOR 16 TAHUN 2019 DALAM UPAYA MEMINIMALISIR PERKAWINAN DINI
}

Uun Dewi Mahmudah, Anik Iftitah, Moh. Alfaris;

Fakultas Hukum Universitas Islam Balitar; Jl. Mojopahit No. 12A Blitar, Jawa Timur;

E-mail : uundewimahmudah98@gmail.com, anikiftitahblitar@gmail.com, Mohalfaris86@gmail.com.

\begin{abstract}
Abstrak
Pada dasarnya, perkawinan berlandasakan pada sisi religiusitas, yang berarti bahwa aspek keagamaan merupakan salah satu dasar pokok dalam menjalankan kehidupan berumah tangga dan ketaqwaan serta keimanan kepada Tuhan. Penelitian ini meneliti kebijakan pembatasan usia perkawinan pasca dihapuskannya perbedaan usia minimal perkawinan dalam UU 1/1974 tentang Perkawinan dengan putusan Mahkamah Konstitusi No. 22/PUU-XV/2017 dan keefektifannya di daerah sebagai refleksi penegakan hukum perkawinan nasional. Peneliti menerapkan pendekatan kualitatif dari jenis penelitian hukum empiris. Data yang diterapkan ialah hasil kombinasi dari data primer dan sekunder, berbentuk penelitian evaluatif yang tujuannya untuk mengevaluasi penerapan suatu penelitian lapangan. Hasil dari penelitian ini menunjukkan bahwa penerapan Pasal 7 Undang-Undang Republik Indonesia No. 16 Tahun 2019 tentang Perkawinan sebagai produk hukum pasca putusan MK di atas di wilayah Kantor Urusan Agama Kec. Garum masih belum efektif.
\end{abstract}

Kata Kunci: Efektivitas, Usia Perkawinan, Perkawinan Dini

Abstract

Basically, marriage is based on religiosity, which means that the religious aspect is one of the main bases in carrying out married life, devotion, and faith in God. This research examines the policy of limiting the age of marriage after abolishing the minimum age difference for marriage in Law 1/1947 concerning marriage with the decision of the Constitutional Court No. 22/PUU-XV/2017 and its effectiveness in the regions as a reflection of national marriage law enforcement. The researcher applies a qualitative approach to the type of empirical legal research. The data applied is the result of a combination of primary and secondary data, in the form of evaluative research that aims to evaluate the application of field research. The results of this study indicate that the application of Article 7 of the Law of the Republic of Indonesia No. 16 of 2019 concerning Marriage as a legal product after the Constitutional Court's decision above in the Garum District Office of Religious Affairs is still ineffective.

Keywords: Effectiveness, Marriage Age, Early Marriage

\section{PENDAHULUAN}

\section{Latar Belakang}

Dalam hukum perkawinan Islam perkawinan berisi unsur-unsur pokok yang sifatnya kerohanian dan kejiwaan. Dimana sifat tersebut mencakup kebenaran, kehidupan lahir batin, serta kemanusiaan. Pada dasarnya perkawinan pula didasarkan pada sisi religiositas, yang berarti aspek keagamaan sebagai salah satu dasar pokok dalam menjalankan kehidupan berumah tangga serta juga menjalankan ketaqwaan dan keimanan pada Allah Swt. Perkawinan menurut Abdurrahman Al-Jaziri merupakan suatu perjanjian suci yang dilakukan antara seorang pria dan wanita untuk membangun sebuah keluarga bahagia. Pengertian tersebut menjelaskan definisi bahwa perkawinan merupakan perjanjian. Selaku perjanjian, perkawinan memuat definisi terdapatnya kesediaan bebas antara dua pihak yang saling mengikat janji dan atas dasar prinsip saling suka. Maka, perkawinan haruslah jauh dari segala unsur termasuk paksaan. 
Perkawinan dalam Pasal 1 Undang-Undang Republik Indonesia No. 1 Tahun 1974 tentang Perkawinan (UUP 1/1974) diartikan sebagai suatu ikatan lahir batin diantara seorang laki-laki dan perempuan selaku suami istri dan bertujuan untuk membangun sebuah keluarga yang kekal dan bahagia berdasar Ketuhanan Yang Maha Esa. Tujuan dari pasangan untuk melangsungkan perkawinan adalah untuk membentuk sebuah keluarga. Keluarga diartikan sebagai lembaga sosial yang bersifat menyeluruh dan ada di seluruh kalangan serta kelompok kemasyrakatan di dunia selain agama. Namun dalam era globalisasi dan semakin majunya kehidupan di dunia ini, kehidupan masyarakat cenderung lebih materialis dan individualis. Selain itu, kontrol sosial juga kian melemah, hubungan antara anak dan orang tua kian bergeser, dan hubungan suami istri kian renggang serta kesakralan keluarga juga kian menipis sehingga hal tersebut dapat menjadi faktor runtuhnya keharmonisan sebuah keluarga.

Oleh sebab itu, di tahun 1974 pemerintah mengeluarkan aturan yang didalamnya diatur mengenai permasalahan perkawinan dan keluarga. Aturan tersebut yakni UUP, dimana salah satu diantara aturan didalamnya mengatur perihal seseorang di dalam masyarakat yang telah dewasa dan akan melangsungkan ikatan perkawinan. ${ }^{1}$ Selama perjalanan empat puluh lima tahun dari penggunaan UUP 1/1974 tersebut, tahun 2017 permohonan judicial review pada pasal 7 ayat (1) UUP diajukan ke Mahkamah Konstitusi Republik Indonesia (MK RI), hal ini karena negara dinilai masih menghendaki pengadaan praktik perkawinan anak, khususnya kepada anak perempuan. Sehingga berakibat pada terlanggarnya penjaminan hak konstitusional pada anak perempuan salah satunya berupa batas usia kawin di dalam hukum tersebut.

Di akhir tahun 2018, MK akhirnya mengabulkan permohonan para pemohon dengan memberi perintah ke pembuat undang-undang selama waktu maksimal 3 tahun agar merevisi pasal 7 ayat (1) UUP 1/1974, ${ }^{2}$ dan kemudian di tahun 2019 revisi tersebut selesai dilakukan dan disahkan serta dijalankan oleh para pemangku kebijakan. Merujuk pada tahun 2019 lalu, berdasarkan data BPS Provinsi Jawa Timur menempatkan Kabupaten Blitar pada urutan ke-14 dari total 38 Kabupaten/Kota di Jawa Timur terkait persentase umur diatas 10 tahun untuk anak perempuan Jawa Timur harus menikah sebelum umur 17 tahun dengan angka 20,01 persen dari rata-rata Jawa Timur 20,64 persen. ${ }^{3}$ Namun selama pandemi Covid-19 sepanjang tahun 2020 lalu, angka perkawinan dini di wilayah Jawa Timur masih menunjukkan persentase yang relatif cukup tinggi yaitu 4,97 persen dibandingkan pada tahun sebelumnya yang hanya 3,6 persen. Mengutip dari data Dinas Pemberdayaan Perempuan, Perlindungan Anak dan Kependudukan (DP3AK) Provinsi Jawa Timur yang diperoleh dari Pengadilan Agama, terjadi 9.453 kasus perkawinan dini dari total 197.068 pernikahan yang tercatat.

Meskipun demikian menurut jumlah kasus di tahun ini terjadi penyusutan di tahun sebelumnya ada sebanyak 11.211 kasus perkawinan anak dari 340.613 perkawinan yang tercatat meskipun persentase tahun 2020 menunjukkan angka yang lebih besar. Secara nasional pada tahun 2019, Jawa Timur menempati posisi ke-22 sebagai provinsi dengan

\footnotetext{
${ }^{1}$ Zahid, Moh. (2002). "Dua Puluh Lima Tahun Pelaksanaan Undang-Undang Perkawinan", Departemen Agama RI Badan Litbang Agama dan Diklat Keagamaan, h. 2.

2 Salinan Putusan Mahkamah Konstitusi Republik Indonesia Nomor 22/PUU-XV/2017, h. 59-60.

${ }^{3}$ Badan Pusat Statistik. (2019). "Persentase Perempuan Jawa Timur Usia 10 Tahun Ke Atas yang Kawin di Bawah Umur (Kurang dari 17 Tahun) menurut Kabupaten/Kota (Persen)". (Online), (https:/ /jatim.bps.go.id/indicator/12/487/1/persentase-perempuan-jawa-timur-usia-10-tahunke-atas-yang-kawin-di-bawah-umur-kurang-dari-17-tahun-menurut-kabupaten-kota.html) diakses pada 22 April 2021.
} 
kasus pernikahan dini sebanyak 11,1 persen menurut data BPS terkait proporsi wanita umur 20-24 tahun yang memiliki status kawin sebelum usia 18 tahun menurut provinsi, dari rata-rata nasional 10,82 persen, yang artinya 1 dari 9 anak perempuan kawin sebelum usianya mencapai 18 tahun. ${ }^{4}$

Seperti yang diketahui, dalam peraturan sebelumnya terdapat perbedaan usia untuk pria dan wanita agar bisa melangsungkan perkawinan, yang kemudian pada tahun 2018 melalui sidang judicial review MK mengeluarkan putusan nomor 22/PUU-XV/2017 yang menegaskan bahwasanya Pasal 7 ayat (1) UUP 1/1974 bertentangan dengan prinsip nondiskriminasi dalam Undang-Undang Dasar Negara Republik Indonesia Tahun 1945 (UUD NRI 1945) serta tidak berkekuatan hukum mengikat, dan menganggap adanya perbedaan minimal usia pada perempuan yang lebih rendah dibandingkan laki-laki yaitu 16 tahun untuk dapat melangsungkan perkawinan juga dinilai sebagai bentuk diskriminasi pada perempuan. Kata diskriminasi di dalam permohonan tersebut dipilih untuk menggambarkan masih adanya perbedaan minimum umur perkawinan untuk wanita dan pria. Padahal konstitusi telah mengamanatkan bahwasanya warga negara bersama dengan kedudukannya di hukum serta pemerintahan harus menjunjung pemerintahan dan hukum tersebut dengan tidak ada pengecualian. ${ }^{5}$ Sehingga aturan di dalam pasal 7 ayat (1) UUP dianggap telah bertentangan dengan konstitusi negara Republik Indonesia. Diskriminasi atau pembedaan perihal usia perkawinan pada pria dan wanita itulah yang dapat mengasumsikan bahwa wanita bisa lebih cepat tumbuh dewasa serta bisa cepat untuk membangun sebuah pernikahan. Padahal di usia 16 tahun atau di bawah usia 21 tahun (usia dewasa perempuan di dalam KUH Perdata) dilihat dari sisi psikologisnya masih belum siap untuk melakukan perkawinan.

Mengutip pernyataan psikolog Anna Surti Ariani saat melakukan wawancara dengan m.hukumonline.com, ${ }^{6}$ dengan membiarkan atau menganjurkan terjadinya perkawinan anak dapat dikatakan sebagai bentuk kekerasan terhadap anak. Hal ini disebabkan karena di usia tersebut fisik anak khususnya pada perempuan masih dalam proses berkembang dan apabila "dipaksa" untuk melakukan hubungan seksual, anak akan lebih rentan terhadap penyakit. Selain dari perkembangan fisik, ketidaksiapan anak untuk menikah di usia tersebut dapat dilihat dari aspek lain diantaranya dari aspek kognitif anak yang secara umum belum memiliki wawasan luas terkait perkawinan, kemampuan menyelesaikan masalah dan membuat keputusan yang belum matang sehingga akan sulit menyelesaikan permasalahan dalam rumah tangganya. Aspek bahasa dan sosial juga turut menjadi alasan mengapa di usia tersebut anak tidak diperbolehkan menikah, karena mereka cenderung susah mengkomunikasikan pikirannya dengan jelas dan kelangsungan hidup sosial anak relatif ada batasan serta akan kurang mendapat dukungan di lingkungannya. Anak yang melakukan pernikahan dini lebih beresiko mengalami depresi dan akan lebih sering bertengkar akibat dari emosi yang masih tidak stabil dan cenderung egois, sehingga akan menyebabkan pernikahan tersebut tidak bahagia. ${ }^{7}$ Dari permasalahan itu, dalam putusan tersebut MK memberi perintah kepada DPR dan pemerintah untuk segera melakukan revisi UUP terkait batasan usia minimal perkawinan khususnya pada perempuan. Kemudian di bulan Oktober 2019 terbitlah

\footnotetext{
${ }^{4}$ Ibid.

${ }^{5}$ Pasal 27 ayat (1) Undang-Undang Dasar Negara Republik Indonesia Tahun 1945.

'Permatasari, Erizka, (2021). "Hukumnya Menikah di Usia Dini". (Online), (https://m.hukumonline.com/klinik/detail/ulasan/lt5b8f402eed78d/hukumnya-menikah-diusia-dini/) diakses pada 21 Juni 2021.

${ }^{7}$ Ibid.
} 
Undang-Undang Republik Indonesia No. 16 Tahun 2019 terkait revisi dari UUP 1/1974. Perubahan tersebut ada pada pasal 7 ayat (1) yang mensyaratkan agar calon pengantin baik perempuan maupun lelaki haruslah sudah berumur 19 tahun untuk melangsungkan perkawinan. Batasan umur perkawinan diatur tujuannya untuk menaikan kualitas SDM Indonesia, serta diharapkan juga dapat menjadi penghambat laju kelahiran anak yang masih cukup tinggi di Indonesia. Selain itu, diharapkan pula hak-hak anak dapat terpenuhi salah satunya agar dapat menuntaskan pendidikannya terlebih dahulu sebelum menikah.

Berdasarkan hasil dari data analisis yang dilakukan oleh Australia-Indonesia Partnership for Justice 2 (AIPJ2) yang bekerja sama dengan MA RI mengenai dampak negatif perkawinan dini baik dari segi kesehatan maupun sosial diantaranya seperti aborsi, kehamilan tidak diinginkan (KTD), penyakit mematikan seperti kanker serviks, HIV/AIDS, KDRT yang dilakukan baik secara fisik dan/atau verbal, terjadinya perceraian hingga kematian ibu akibat melahirkan di usia yang masih sangat muda. Sehingga keefektivitasan penerapan batas minimal usia untuk melaksanakan perkawinan yang baru ini menjadi tanggung jawab para pemangku kebijakan dari Pengadilan Agama maupun Pengadilan Negeri, Pegawai Pencatat Perkawinan dan pemerintah pusat maupun daerah. Namun demikian, kesadaran masyarakat dalam hal ini menjadi yang utama agar kebijakan tersebut dapat berjalan sebagaimana mestinya. Tingkat keefektivitasan suatu peraturan atau kebijakan dapat dinilai dari beberapa faktor, seperti faktor hukum itu sendiri, dari penegak hukum, sarana maupun fasilitas pendukung penegakan hukum tersebut, dari masyarakatnya hingga dari kebudayaan lingkungan di mana hukum tersebut ditegakkan. ${ }^{8}$ Sehingga berlandaskan latar belakang di atas, peneliti berminat untuk melaksanakan penelitian terkait permasalahan efektivitas penerapan batas minimal usia melangsungkan perkawinan dengan mengaitkan pada upaya meminimalisir kejadian perkawinan anak di bawah umur, dengan judul "Efektivitas Penerapan Pasal 7 Undang-Undang Perkawinan Nomor 16 Tahun 2019 dalam Upaya Meminimalisir Perkawinan Dini."

\section{Rumusan Masalah}

Mengacu latar belakang di atas, sehingga penelitian ini akan menarik perumusan masalah bagaimanakah keefektivitasan penerapan Pasal 7 Undang-Undang Perkawinan dalam upaya meminimalisir perkawinan dini?

\section{METODE PENELITIAN}

Penulisan dalam riset ini menerapkan jenis penelitian hukum empiris, dari pendekatan yuridis sosiologis, serta bentuk riset evaluatif yang dimaksudkan untuk mengkaji pelaksanaan peraturan perundangan-undangan melalui cara mengamati realita yang terdapat di lapangan berkenaan dengan perkara yang akan dikaji ditilik dari sudut implementasi hukum. ${ }^{9}$ Sehingga penyusunan lebih menitikberatkan pada studi lapangan, yaitu memakai gabungan dari data primer dan sekunder dari menerapkan teknik pengumpulan data metode purposive sampling serta kemudian dianalisis secara kualitatif

\footnotetext{
8 Soekanto, S. (2016). "Faktor-Faktor yang Mempengaruhi Penegakan Hukum." Depok: Raja Grafindo Persada, h. 8.

9 Admin. (2014). "Contoh Proposal Metode Penelitian Hukum-Aspek Yuridis Pemilihan Anggota Badan Perwakilan Desa", (Online), (https://www.contoh-proposal-metode-penelitian-hukumaspek-yuridis-pemilihan-anggota-badan-perwakilan-desa.html) diakses pada 20 Maret 2021.
} 
untuk menarik konklusi sebagai tanggapan dari persoalan yang ada. Penelitian dilakukan dengan pengambilan lokasi di KUA Kec. Garum, Kab. Blitar dimana waktu penelitian diadakan di bulan Februari 2021 dan Juli 2021.

\section{PEMBAHASAN}

\section{A. Kebijakan Pembatasan Usia Perkawinan Pasca Dihapuskannya Perbedaan Usia Minimal Perkawinan}

Di Indonesia, sebelumnya kebijakan hukum terkait perkawinan telah diatur dengan cukup baik di dalam Undang-Undang Republik Indonesia No. 1 Tahun 1974 tentang Perkawinan (UUP 1/1974), pada ketentuan tersebut tidak saja memerhatikan perkawinan dari faset formal saja tetapi turut memerhatikan dari faset agama sebagaimana yang sudah tercantum pada pasal 1 dan pasal 2 UUP 1/1974. ${ }^{10}$ Menilik dari aspek formal di dalamnya menetapkan ketentuan administatif perkawinan sedangkan untuk aspek agama sendiri di dalamnya telah ditetapkan terkait keabsahan suatu perkawinan, sehingga apabila salah satu aspek tidak dipenuhi, maka perkawinan tidak sah menurut ketentuan tersebut. Perkawinan ialah hak konstitusional setiap warga negara yang tidak diperbolehkan adanya pelarangan untuk individu agar bisa melaksanakan perkawinan selama memenuhi ketentuan hukum dalam Undang-Undang Perkawinan yang berlaku. Hal itu dipertegas dengan dituangkan serta diamanatkan oleh Konstitusi Negara Republik Indonesia yaitu UUD NRI 1945 pada ketentuan pasal 28 B ayat (1) dimana "Setiap orang berhak membentuk keluarga dan melanjutkan keturunan melalui perkawinan yang sah" namun berbeda jika yang akan melangsungkan perkawinan seseorang yang usianya masih terlalu muda, maka sudah sangat wajar jika diatur mengenai ketentuan batas usia kawin sebagai salah satu alat pengawasan bagi negara. ${ }^{11}$

Kebijakan dari adanya penetapan batasan usia kawin memiliki tujuan untuk kebaikan dan kemaslahatan terutama bagi calon pengantin. Dalam memastikan tercapai atau tidaknya tujuan tersebut maka ditetapkanlah prinsip batasan usia kawin seperti yang telah dituangkan dalam UUP nomor 4 huruf (d) yang menyatakan "dasar utama pada peraturan pembatasan usia kawin bukan hanya urusan usia semata namun juga tentang kematangan jiwa dan raga calon pengantin, agar perkawinan yang akan dijalankan menjadi perkawinan yang harmonis serta kelak memperoleh keturunan secara sehat." Maka sebab itu, pemangku kebijakan dalam membuat undang-undang selain menetapkan aturan mengenai batasan usia kawin juga masih turut memberikan ruang bagi mereka yang berusia "illegal" untuk kawin agar masih dapat mengadakan perkawinan melewati dispensasi kawin yang ditujukan ke

10 Yunus, A. (2020). "Hukum Perkawinan dan Itsbat Nikah: Antara Perlindungan dan Kepastian Hukum". humanities genius.

11 Aldi J.A., E.P. Tanbun, \& X. Nugraha. (2019). “Tinjauan Yuridis Kewenangan Dewan Kehormatan Penyelenggara Pemilu (DKPP) dalam Menciptakan Pemilu yang Demokratis di Indonesia". Jurnal Hukum De' rechtsstaat, Volume 5 Nomor 2, h. 137. 
pengadilan sesuai dengan agama calon pemohon dispensasi menurut pada pasal 7 ayat (2) UUP 1/1974.

Pengertian dispensasi kawin menurut Peraturan Mahkamah Agung Republik Indonesia (PERMA RI) Nomor 5 Tahun 2019 adalah penetapan yang berupa pengistimewaan untuk bakal pengantin yang masih belum layak usianya untuk tetap dapat melangsungkan pernikahan sebagai pengkhususan pembatasan usia kawin. ${ }^{12}$ Peran majelis hakim dalam proses penetapan dispensasi kawin dinilai sangat krusial sebagai pengontrol prinsip utama dalam kebijakan pembatasan usia kawin. Diaturnya mengenai batasan usia minimal kawin menjadi sesuatu yang penting untuk dilakukan dalam upaya perlindungan hukum terhadap perempuan Indonesia. Sebelumnya dalam pasal 7 ayat (1) UUP 1/1974 batasan umur kawin seseorang dibedakan antara perempuan serta laki-laki yakni 16 dan 19 tahun. Sehingga kebijakan baru terkait masalah batas minimum usia kawin pada perempuan menjadi suatu hal yang cukup penting untuk dilakukan perubahan sebagai salah satu upaya perlindungan hukum serta wujud dari peniadaan diskriminasi terhadap wanita.

Perjuangan guna mendapatkan kesetaraan minimal usia dalam melakukan perkawinan membuahkan hasil, di tahun 2018 melalui putusan Mahkamah Konstitusi Republik Indonesia (MK RI) yang bernomor 22/PUU-XV/2017. MK sebagai pengawal hak konstitusi warga negara dan dalam rangka pencegahan semakin jauhnya ketidaksetaraan yang terjadi antara pria dan wanita, oleh sebab itu MK memberi pengabulan sebagian permohonan dari para pemohon dengan menegaskan Pasal 7 ayat (1) UUP sepanjang frasa "umur 16 tahun" memang bersimpangan dengan konstitusi (UUD NRI 1945) serta tidak berkekuatan hukum mengikat." Selanjutnya berdasarkan pada perubahan UUP 1/1974 menjadi UU Perkawinan No. 16 Tahun 2019 yang telah diterbitkan serta mulai dilaksanakan pada 15 Oktober 2019 ini memiliki perbedaan dalam hal ketentuan terkait perkawinan usia dini. Adapun perbedaan tersebut disajikan dalam tabel perbedaan berikut:

\begin{tabular}{|c|c|c|}
\hline Perihal & $\begin{array}{c}\text { Undang-Undang } \\
\text { Perkawinan Nomor 1 } \\
\text { Tahun 1974 }\end{array}$ & $\begin{array}{c}\text { Undang-Undang Perkawinan Nomor 16 } \\
\text { Tahun 2019 }\end{array}$ \\
\hline $\begin{array}{c}\text { Usia minimal } \\
\text { kawin }\end{array}$ & $\begin{array}{c}\text { 19 tahun untuk laki-laki } \\
\text { dan 16 tahun untuk } \\
\text { perempuan }\end{array}$ & $\begin{array}{c}\text { Pria dan perempuan harus telah berumur } \\
19 \text { tahun. }\end{array}$ \\
\hline Dispensasi & Dimungkinkan & $\begin{array}{c}\text { Dimungkinkan dengan syarat, apabila } \\
\text { calon pengantin masih berusia kurang } \\
\text { dari 15 tahun wajib untuk mendapatkan } \\
\text { rekomendasi dari psikolog, KPAI/KPAD, } \\
\text { maupun P2TP2A. }\end{array}$ \\
\hline Otoritas & $\begin{array}{c}\text { Pengadilan atau pejabat } \\
\text { lain yang ditunjuk oleh } \\
\text { kedua orangtua pihak }\end{array}$ & $\begin{array}{c}\text { Pengadilan Agama bagi yang agamanya } \\
\text { Islam dan Pengadilan Negeri untuk selain } \\
\text { Islam. }\end{array}$ \\
\hline
\end{tabular}

12 Pasal 1 angka 5 PERMA RI No. 5 Tahun 2019. 


\begin{tabular}{|c|c|c|}
\hline $\begin{array}{c}\text { Orang tua/wali } \\
\text { calon pengantin }\end{array}$ & $\begin{array}{c}\text { Memberi pengajuan } \\
\text { dispensasi kawin. }\end{array}$ & $\begin{array}{c}\text { Memberi pengajuan dispensasi kawin dan } \\
\text { harus memberikan keterangan pada } \\
\text { waktu persidangan di pengadilan. }\end{array}$ \\
\hline
\end{tabular}

Sumber: Data Sekunder, 2021

Perbedaan kebijakan dari ketentuan sebelumnya yang telah sedikit diuraikan dalam tabel di atas, turut dipertegas dengan kebijakan baru yang terdapat pada Peraturan Mahkamah Agung Republik Indonesia (PERMA RI) Nomor 5 Tahun 2019 sebagai acuan dalam mengadili permohonan pengecualian kawin. Kebijakan pada pasal 7 UU Perkawinan memberikan peringatan bahwa untuk dapat melakukan perkawinan dengan usia yang kurang haruslah mengajukan dispensasi kawin ke pengadilan selaras dengan agama yang dipercaya oleh calon pengantin terlebih dahulu dengan syarat bahwa perkawinan tersebut "urgent" untuk segera dilakukan. Maka dalam PERMA tersebut diatur terkait bagaimana hakim harus memberi pertimbangan-pertimbangannya menyangkut kepentingan yang paling baik untuk anak. Seperti dalam pertimbangan tersebut hakim haruslah mempelajari dengan seksama dan teliti serta cermat terkait dengan permohonan pemohon, mencari informasi terkait persetujuan dan pemahaman dari anak untuk dikawinkan, memerhatikan ketidaksamaan umur antara anak dengan pasangannya, serta dipertimbangkannya keadaan kesehatan, pendidikan, psikologi sosiologis, ekonomi dari anak dan orang tuanya berdasar anjuran dari psikolog maupun lembaga terkait. Selain itu hakim haruslah cermat dalam menerima keterangan dari pemohon, anak dan calon pasangan terkait dengan ada tidaknya unsur memaksa dari sisi mental, fisik, ekonomi ataupun seksual, serta pemastian bahwa orang tua benar-benar berkomitmen untuk turut bertanggung jawab dalam hal masalah ekonomi, kesehatan, sosial maupun pendidikan anak. ${ }^{13}$ Sehingga masih diharapkan dengan adanya revisi tersebut dapat meminimalisir atau bahkan dapat meniadakan kasus perkawinan usia dini di Indonesia.

\section{B. Efektivitas Penerapan Pasal 7 Undang-Undang Perkawinan dalam Upaya Meminimalisir Perkawinan Dini}

Berdasarkan keadaan-keadaan yang mempengaruhi keefektivitasan suatu hukum yang diungkapkan oleh Soerjono Soekanto pada bukunya mengenai "Faktor-Faktor yang Mempengaruhi Penegakan Hukum" terdapat lima elemen yang menentukan efektif ataukah tidak sebuah hukum. Mengacu kelima faktor tersebut, terdapat dua faktor utama yang mempengaruhi terjadinya perkawinan dini di Indonesia. Kedua faktor tersebut yakni faktor dari undang-undang itu sendiri atau hukum serta dari faktor masyarakat atau lingkungan dimana hukum tersebut diterapkan ataupun berlaku. Dari segi undang-undangnya, aturan mengenai pembatasan usia agar seseorang dapat melangsungkan perkawinan dinilai akan cukup efektif untuk menekan terjadinya perkawinan di bawah usia legal. Namun sudah menjadi hal yang

${ }^{13}$ Pasal 16 PERMA RI Nomor 5 Tahun 2019 tentang Pedoman Mengadili Permohonan Dispensasi Kawin. 
lumrah apabila terjadi perubahan atau pergantian suatu kebijakan akan berakibat pada saat diterapkannya kebijakan tersebut di masyarakat. Seperti akibat dari disamakannya usia kawin pada perempuan dan laki-laki dalam UU Perkawinan Pasal 7 ayat (1).

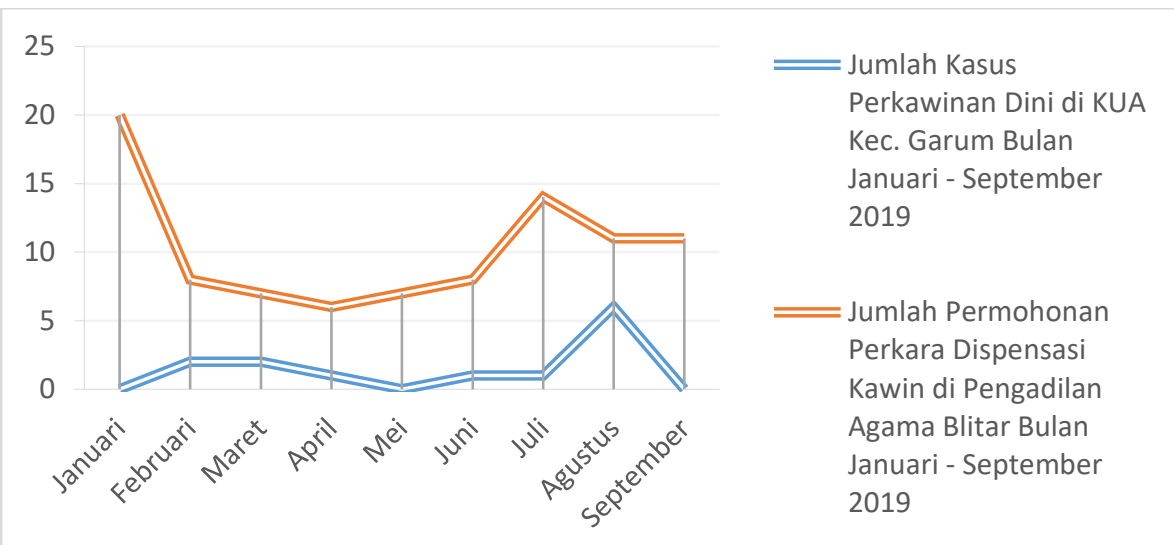

Grafik 1.1 Jumlah Permohonan Dispensasi Kawin dan Kasus Perkawinan Dini di Kec. Garum Sebelum Revisi UUP 1/1974

Di mana data tersebut diambil dalam 9 bulan sebelum diterapkannya Pasal 7 UU Perkawinan, angka permohonan kasus dispensasi kawin di Pengadilan Agama Blitar hanya di kisaran angka 20 permohonan per bulan, dengan kasus perkawinan dini di KUA Kec. Garum yang berada di kisaran 0 hingga 6 kasus per bulan. Sedangkan hasil penelitian dokumen yang telah dilaksanakan dengan rentan waktu 9 bulan setelah diberlakukannya revisi pasal 7 UU Perkawinan diketahui bahwa grafik menunjukkan peningkatan kasus.

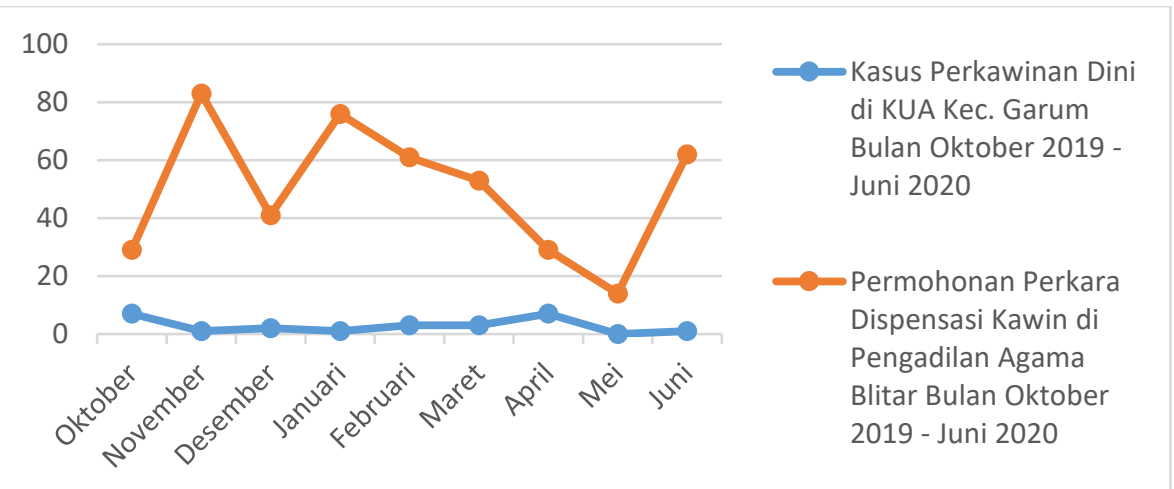

Grafik 1.2 Jumlah Permohonan Dispensasi Kawin dan Kasus Perkawinan Dini di Kec. Garum Setelah Revisi UUP 1/1974

Seperti yang dapat dilihat dari grafik yang telah disajikan, perkara permohonan dispensasi kawin mengalami kenaikan signifikan berada dikisaran angka 14 hingga 83 perkara per bulan, empat kali lipat lebih banyak dari yang sebelumnya. Sedangkan untuk perkawinan dini yang terjadi selama 9 setelah adanya revisi pasal 7 tersebut di KUA Kec. Garum tidak banyak mengalami kenaikan, hanya berada di kisaran angka 0 hingga 7 kasus per bulan. Dapat disimpulkan bahwa angka permohonan dispensasi kawin bisa dijadikan sebagai cerminan dari banyaknya angka perkawinan usia dini. Hal ini karena dispensasi usia minimal kawin saat ini menjadi jalan yang 
diperbolehkan oleh undang-undang untuk tetap dapat melakukan perkawinan dini sesuai dengan prosedur hukum yang berlaku. Terkait kebijakan baru mengenai batas umur minimal kawin yang disamakan baik itu laki-laki maupun perempuan dalam upaya meminimalkan kasus perkawinan dini, hasil dari wawancara bersama Bapak Drs. H. Abu Syakur, M.H., sebagai hakim Pengadilan Agama Blitar yang peneliti lakukan pada hari Selasa, 10 Agustus 2021.

"Bahwa kebijakan pembatasan usia kawin tersebut masih belum cukup efektif dalam pencegahan perkawinan dini di Blitar dilihat dari perkara permohonan dispensasi kawin yang masuk dengan tren per bulannya yang masih cenderung naik." 14

Dalam wawancara tersebut peneliti turut menanyakan terkait mengapa masih banyak kasus permohonan dispensasi kawin yang dikabulkan oleh hakim bahkan 99,99 persen tidak ada yang ditolak?

Menurut beliau "dasar pertimbangan hakim dalam mengabulkan perkara dispensasi kawin yaitu berdasarkan kaidah fiqiyah yang menyatakan untuk menghindari suatu kerusakan daripada menarik suatu kebaikan."

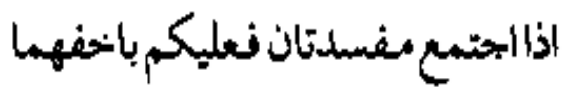

"Apabila berkumpul dua bahaya, maka hendaklah kalian berpegang pada salah satu yang lebih ringan bahayanya";

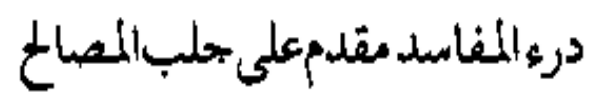

"Menolak atau menghindari mafsadah (kerusakan) itu harus didahulukan dari pada menarik sesuatu maslahah (kebaikan)";

Salah satu contoh kasus yang beliau sampaikan yaitu ketika si pemohon sudah memiliki teman dekat atau pacar dan hubungannya sudah terlalu dekat dan ditakutkan akan terjadi pelanggaran norma agama sehingga diputuskan untuk menikah meskipun usianya belum cukup untuk kawin. Oleh karena dasar pertimbangan hakim adalah menghindarkan diri dari suatu keburukan atau kerusakan haruslah didahulukan daripada menarik kebaikan sehingga permohonan dispensasi kawin tersebut harus dikabulkan. Namun seperti yang telah disampaikan pada saat dilakukannya wawancara tersebut, terkait syarat permohonan dispensasi kawin guna meminimalisir terjadinya perkawinan anak terdapat persyaratan administrasi seperti; ${ }^{15}$

a. Fotokopi ijazah pendidikan terakhir anak atau surat keterangan masih sekolah dari sekolah anak;

b. Fotokopi kartu keluarga (KK);

c. Fotokopi KTP atau kartu identitas anak (KIA) atau akta kelahiran calon suami atau istri;

d. Fotokopi KTP orangtua atau wali

${ }^{14}$ Wawancara bersama dengan Hakim Pengadilan Agama Blitar Bapak Drs. H. Abu Syakur, M.H. pada Selasa, 10 Agustus 2021.

${ }_{15}$ Pasal 5 ayat (1) PERMA RI Nomor 5 Tahun 2019 tentang Pedoman Mengadili Permohonan Dispensasi Kawin. 
e. Surat permohonan dispensasi kawin.

Hakim juga turut memberikan syarat kepada pemohon sebagai salah satu bahan pertimbangan dalam memutuskan dikabulkan atau ditolaknya permohonan dispensasi kawin yaitu adanya saran dari dokter/bidan atau psikolog, P2TP2A, maupun rekomendasi dari Komisi Perlindungan Anak Indonesia/Daerah (KPAI)/(KPAD). ${ }^{16}$ Selain itu, dari hasil wawancara pada Jum'at, 23 Juli 2021 yang telah peneliti lakukan dengan Bapak Muh. Syihabuddin, M.Ag. selaku kepala kantor urusan agama (KUA) Kecamatan Garum,

"Angka perkawinan dini di wilayah Kecamatan Garum sampai dengan pertengahan tahun 2021 setelah adanya revisi UUP dinilai sedikit efektif dalam mengurangi jumlah perkawinan usia dini di wilayah KUA Kecamatan Garum, lanjutnya untuk tahun 2021 sampai pertengahan tahun ini angka perkawinan usia dini di wilayah kerjanya mengalami sedikit penurunan kisaran angka sepuluh hingga dua puluh persen dikomparasi dengan beberapa tahun sebelumnya. Hal ini disebabkan selain adanya perubahan aturan mengenai batas minimal usia untuk dapat melakukan perkawinan juga akibat dari adanya pandemic Covid-19 yang menimpa seluruh negara termasuk Indonesia, sehingga pemerintah membuat kebijakann baru untuk meniadakan beberapa kegiatan masyarakat seperti hajatan perkawinan."17

Sedangkan untuk penerapan pasal 7 UU Perkawinan No. 16 Tahun 2019 jika dilihat dari faktor masyarakat atau lingkungan dimana hukum tersebut diterapkan cenderung lebih sering memilih untuk melakukan perkawinan di usia dini. Sehingga hal ini berbanding terbalik dengan semangat undang-undang untuk menurunkan angka kasus perkawinan dini di Indonesia. Ada berbagai alasan yang menjadi pertimbangan dalam pengajuan permohonan dispensasi kawin diantaranya si anak yang menginginkan untuk melangsungkan ikatan perkawinan, sudah bertunangan, atau karena orangtua yang menghendaki menikahkan anaknya yang telah memiliki teman lawan jenis sehingga dibanding ikut terpengaruh dalam tindakan yang terlarang oleh agama atau norma di masyarakat, lebih buruknya lagi pengajuan permohonan dispensasi kawin dilakukan karena dari pihak wanita sudah mengandung lebih dulu. ${ }^{18}$

Sebutan bujang lapuk dan perawan tua untuk mereka yang belum menikah di usia siap kawin merupakan kata yang berkonotasi negatif sehingga mendoktrin pola pikir orangtua untuk mengkawinkan anaknya di usia yang belia. Faktor ekonomi dan rendahnya pendidikan turut serta menjadi salah satu faktor pendukung timbulnya perkawinan di usia yang terbilang muda. Karena orangtua yang mengalami keterpurukan ekonomi dan miskin beranggapan jika perekonomian keluarga akan

16 Pasal 15 huruf (d) PERMA RI Nomor 5 Tahun 2019 Tentang Pedoman Mengadili Permohonan Dispensasi Kawin.

17 Wawancara dengan Kepala KUA Kecamatan Garum Bapak Muh. Syihabuddin, M.Ag. pada Jum'at, 23 Juli 2021.

${ }^{18}$ Mayasari, Dian Ety; Atjengbharata, Andreas L. (2020). "Pengaturan Batas Usia untuk Melakukan Perkawinan Ditinjau dari Undang-Undang Perlindungan Anak." DiH: Jurnal Ilmu Hukum. Volume 16 Nomor 2. Agustus 2020, h. 242. 
ringan apabila anak-anaknya telah menikah. ${ }^{19}$ Sehingga dalam hal ini orangtua turut andil dalam perkawinan anaknya padahal sebagaimana yang diungkapkan Maidin Gultom menegaskan "pada dasarnya anak tidak memberi perlindungan kepada dirinya pribadi dari segala jenis perbuatan yang menyebabkan kerugian baik secara pikiran, fisik, maupun sosial dalam berbagai lingkup penghidupan serta kelangsungan hidup." 20 Namun untuk merealisasikan apa yang telah diekspektasikan tidak selalu sama dengan realita yang terjadi di lapangan.

Sama halnya seperti yang dikatakan oleh Bapak Muhamad Chairul, S.H selaku pengacara yang berkantor di Kantor Advokat "Karyono, S.H. and Partners" saat dilakukannya wawancara pada tanggal 28 Juli 2021, beliau mengatakan:21

"bahwa untuk mengefektifkan suatu kebijakan perlu adanya peran serta dari seluruh pemangku kepentingan dan dari masyarakat itu sendiri. Karena dalam hal penerapan batas usia minimal kawin yang baru tidak akan bisa jika dilakukan oleh salah satu pihak saja, oleh sebab itu penerapan dari pasal 7 UU Perkawinan dinilai masih belum efektif untuk menurunkan angka kasus perkawinan dini. Contohnya dalam beberapa waktu kebelakang terdapat 5 (lima) kasus permohonan dispensasi kawin yang masuk dikantor tersebut dengan alasan atau penyebab paling banyak mengajukan dispensasi kawin karena memang usianya yang masih kurang menurut UU Perkawinan dan untuk penyebab karena hamil duluan menurut beliau hanya dikisaran 25 (dua puluh lima) persen bahkan hampir tidak ada."

Sama halnya dengan pernyataan dari Bapak Tri Elyas Setyawan, S.H. pengacara yang berkantor di Kantor Advokat "Sekawan \& Partners" yang mengatakan bahwa: 22

"adanya aturan baru mengenai pembatasan minimal usia kawin masih belum berjalan efektif sesuai dengan harapan dari perubahan tersebut. Sebelumnya di tahun 2017 hingga 2018 angka kasus dispensasi kawin yang ditangani hanya di kisaran 2 sampai 3 kasus saja, namun setelah adanya perubahan minimal kawin di tahun 2020 kasus yang ditangani mengalami peningkatan yang cukup pesat yaitu 21 kasus pengajuan dispensasi kawin dengan wilayah terbanyak yang mengajukan dan ditanganinya adalah Kecamatan Ponggok. Rata-rata mereka yang mengajukan dispensasi kawin berada di usia 16 tahun hingga 17 tahun, dengan alasan sudah hamil terlebih dahulu, maupun hubungan yang sudah sedemikan eratnya."

Lebih dari itu peneliti turut melakukan wawancara terkait kasus perkawinan dini dengan salah satu modin desa Karangrejo, Bapak Djauhari, pada tanggal 21 Juli 2021. Dalam wawancara tersebut peneliti mengajukan sedikit pertanyaan perihal dalam satu tahun atau beberapa bulan terakhir pernah atau tidaknya beliau membantu untuk menangani atau mengajukan dispensasi kawin ke Pengadilan Agama Blitar dari warganya, dan beliau mengatakan

"dalam beberapa bulan terakhir beliau sedang menangani 2 (dua) kasus perkawinan anak, salah satu diantara kasus tersebut juga sudah dikabulkan oleh hakim. Mengenai penyebab dari pengajuan

19 Ramadhita. (2014). "Diskresi Hukum : Pola Penyelesaian Kasus Dispensasi Perkawinan", De Jure Jurnal Syariah dan Hukum, Fakultas Syariah UIN Maulana Malik Ibrahim Malang, Volume 6. Nomor 1, h. 66.

${ }^{20}$ Gultom, Maidin. (2014). Perlindungan Hukum terhadap Anak dan Perempuan. Bandung: Refika Aditama, h. 69.

${ }^{21}$ Wawancara dengan Sekretaris DPC Peradi Blitar, Bapak Muhamad Chairul, S.H. pada 28 Juli 2021.

22 Wawancara bersama Bapak Tri Elyas Setyawan, S.H. pada 24 Agustus 2021. 
dispensasi kawin tersebut adalah karena memang usianya yang masih kurang untuk kawin dan sudah tidak bisa dipisahkan." 23

Mengenai penyebab atau alasan yang mendasari terjadinya perkawinan usia dini di wilayah Kecamatan Garum sendiri, menurut kepala KUA Kecamatan Garum

"alasan paling banyak yaitu karena pergaulan bebas yang menyebabkan si anak perempuan hamil terlebih dahulu, kemudian karena sudah dilamar dan masalah rendahnya pendidikan serta orang tua yang kurang memberi perhatian serta kasih sayangnya. Sedangkan alasan yang menyangkut permasalahan ekonomi keluarga menurutnya sangat rendah bahkan hampir tidak ada. Untuk alasan minor dari penyebab terjadinya perkawinan dini di wilayah Kec. Garum yaitu terkait dengan budaya masyarakat."

Terkait pertanyaan mengenai bagaimana hukumnya menikahkan seorang wanita dalam keadaan hamil, menurut kepala KUA Kec. Garum hukum menikahkan perempuan hamil yaitu boleh, asalkan saat hamil ia belum pernah menikah. Tambah beliau, yang tidak boleh dinikahkan saat dalam keadaan hamil yaitu saat calon pengatin wanita hamil dan akan melangsungkan perkawinan namun masih dalam masa 'iddah. Berdasarkan hasil penelitian terhadap 20 sampel dari 38 kasus perkawinan dini yang diambil secara acak di tahun 2019 hingga tahun 2020, penyebab terbanyak perkawinan dini di wilayah KUA Kec. Garum yaitu faktor usia yang memang masih kurang menurut undang-undang dan karena sudah dilamar dengan calon suaminya dengan persentase 35 persen dan 30 persen, sehingga dapat dipetakan sebagai berikut:

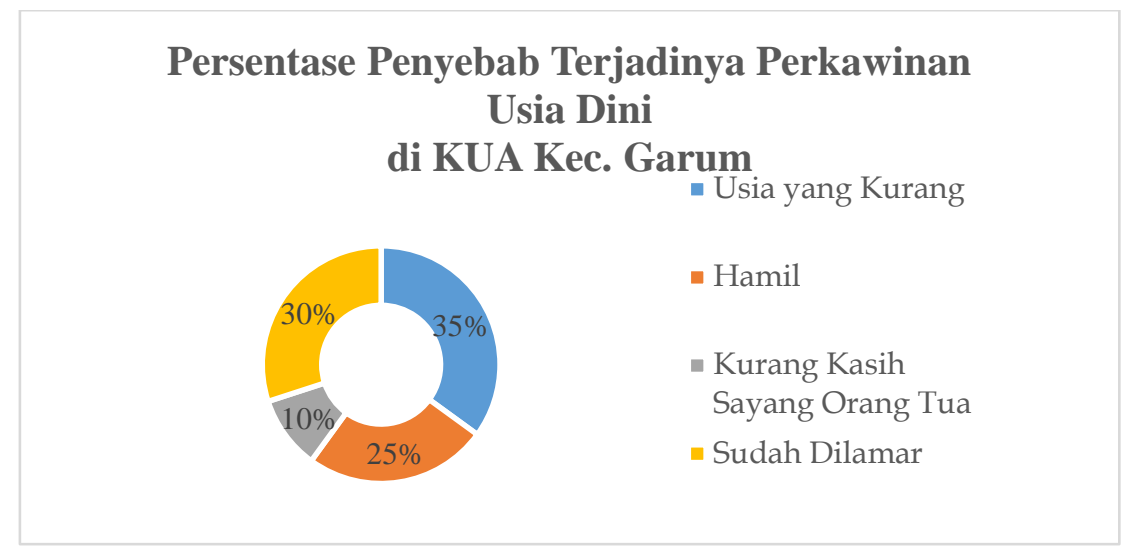

Diagram 1.1 Persentase Penyebab Terjadinya Perkawinan Usia Dini di KUA Kec. Garum

Selain itu, agar lebih mengetahui permasalahan mengapa orang tua menyetujui untuk mengawinkan anaknya di usia yang masih belum legal menurut undangundang perkawinan yang berlaku, peneliti melaksanakan wawancara bersama salah satu orang tua calon pengantin perempuan yang melakukan konsultasi terkait syarat mengawinkan anaknya yang masih di bawah umur di KUA Kec. Garum pada tanggal 23 Februari 2021. Di mana ibu dari anak tersebut mengatakan ${ }^{24}$

"bahwa anaknya yang pada saat itu masih sekolah di salah satu sekolah menengah kejuruan (SMK) swasta di Kota Blitar melakukan praktik kerja lapangan di salah satu toko makanan burung di wilayah Kabupaten Blitar, si anak berkenalan dengan salah satu pembeli laki-laki di toko tersebut

23 Wawancara dengan Bapak Djauhari pada 21 Juli 2021.

24 Wawancara bersama orang tua pelaku perkawinan dini pada 23 Februari 2021. 
dan kemudian menjalin hubungan tanpa sepengetahuan dari orang tuanya dan kemudian selang beberapa bulan saat anaknya berada di rumah si ibu merasa ada yang aneh terhadap tingkah laku si anak. Setelah dicecar dengan banyak pertanyaan oleh orang tuanya si anak mengaku jika ia telah mengandung hasil dari hubungan yang ia lakukan dengan laki-laki yang ia kenal saat melakukan praktik kerja lapangan di toko tempat ia melakukan praktik kerja lapangan. Karena hal tersebut dan orangtua sudah kepalang malu jika anaknya harus memiliki anak tanpa menikah, dengan terpaksa orangtua menyetujui untuk dilakukannya perkawinan meskipun si anak masih berusia 18 tahun."

Sedangkan untuk pelaku perkawinan usia dini di wilayah KUA Kecamatan Garum di dominasi dengan jenis kelamin perempuan.

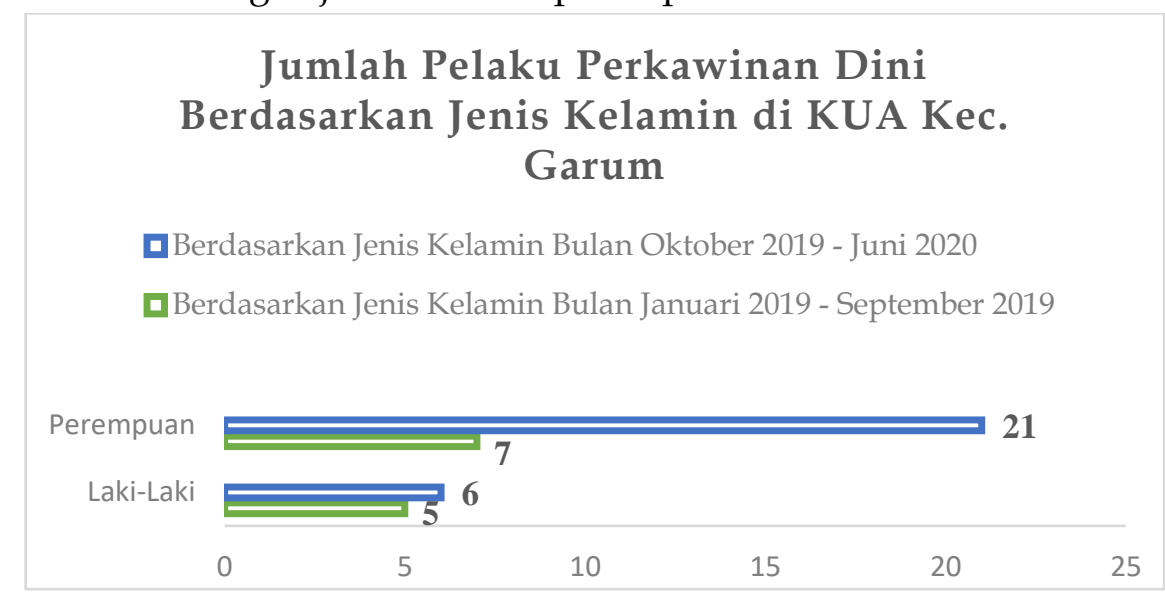

Diagram 1.2 Jumlah Pelaku Perkawinan Dini Berdasarkan Jenis Kelamin di KUA Kec. Garum

Terkait dengan usia yang melakukan perkawinan dini di KUA Kecamatan Garum sendiri, hasil menunjukkan bahwa 42 persen pelaku perkawinan dini masih berada di usia 17 tahun. Selain itu minoritas pelaku perkawinan usia dini berada di usia 16 dan 15 tahun.

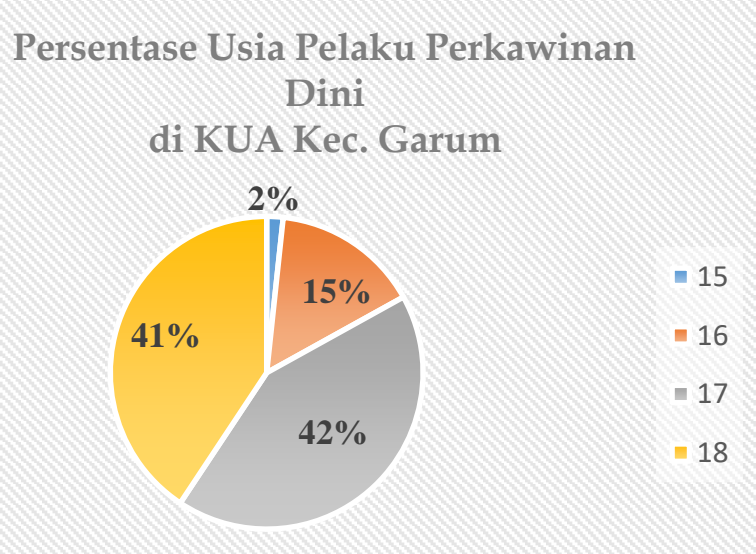

Diagram 1.3 Persentase Usia Pelaku Perkawinan Dini di KUA Kec. Garum

Berdasarkan peningkatan angka perkawinan usia dini pada data-data yang telah disajikan dalam bentuk grafik maupun diagram di atas, dapat dilihat dari usia pelaku perkawinan dini, mereka masihlah anak-anak yang seharusnya masih mengenyam pendidikan di sekolah, sehingga menurut peneliti aturan terkait wajib belajar dua belas tahun haruslah diselaraskan dengan syarat administrasi untuk mengajukan perkawinan. Namun demikian, dengan mewajibkan belajar dua belas tahun pemerintah harus turut serta memberikan sokongan dalam hal biaya sekolah yang 
harus terjangkau atau bisa jadi dapat digratiskan agar tujuan dari pembatasan usia minimal kawin dapat tercapai. Kembali lagi, adanya perubahan terkait usia minimal kawin dalam upaya meminimalisir perkawinan dini dalam satu tahun sejak diundangkan dan diterapkannya Pasal 7 UU Perkawinan masih tidak berjalan efektif dalam mengurangi laju perkawinan dini di wilayah KUA Kecamatan Garum.

Dalam menerapkan Pasal 7 UU Perkawinan sebagai upaya meminimalkan terjadinya perkawinan dini di Indonesia umumnya, ternyata masih memiliki beberapa kelemahan yang dapat menghambat tercapainya tujuan dari diubahnya Pasal 7 UUP. Kelemahan-kelemahan tersebut diantaranya:

a. Masih minimnya perhatian dari pemerintah;

b. Masih kurangnya sosialisasi dari pemerintah terkait perkawinan dini dilingkup terkecil dalam masyarakat;

c. Kurangnya orang atau biaya dalam melakukan sosialisasi di tengah masyarakat;

d. Orang tua masih belum memahami terkait aturan baru mengenai batas minimal usia kawin;

e. Pergaulan anak yang sudah terlalu bebas;

f. Media sosial yang masih berkontribusi menyumbang konten negatif dan kurangnya pengawasan dari orangtua saat anak berselancar di dunia maya.

Padahal seperti yang kita ketahui tujuan dari diubahnya pasal 7 atau pasal terkait batas usia minimal kawin tersebut adalah agar di Indonesia angka perkawinan usia dini dapat berkurang dan bahkan tidak ada lagi. Sehingga dengan adanya peningkatan jumlah kasus tersebut sangat bertolak belakang dari tujuan awal diubahnya Pasal 7 Undang-Undang Republik Indonesia No. 16 Tahun 2019 mengenai pembaharuan dari Undang-Undang Republik Indonesia No. 1 Tahun 1974 Terkait Perkawinan.

\section{PENUTUP}

Perubahan kebijakan tersebut, turut memberikan dampak dalam peningkatan angka perkawinan dini di KUA Kec. Garum yakni dalam kisaran satu persen dalam sembilan bulan sejak diterapkannya aturan tersebut yang pada sembilan bulan sebelum diterapkannya kebijakan tersebut hanya dikisaran nol hingga enam kasus per bulan. Menimbang hal tersebut, penerapan pasal 7 dalam upaya meminimalisir terjadinya perkawinan dini di KUA Kec. Garum, Kab. Blitar, Indonesia terbukti masih tidak efektif. Upaya yang dapat dilakukan guna memaksimalkan penerapan perubahan minimum batas umur kawin pada pasal 7 UU Perkawinan No. 16 Tahun 2019 yaitu dengan memaksimalkan sosialisasi terkait aturan tersebut, mengenai dampak kesehatan untuk calon ibu yang masih berusia di bawah ketentuan, menyelaraskan aturan mengenai wajib belajar dua belas tahun sebagai salah satu syarat dalam pengajuan perkawinan, peran serta masyarakat khususnya orang tua dalam mengawasi dan/atau mengontrol anakanaknya agar tidak masuk ke dalam pergaulan yang salah dan tumbuh menjadi anak yang lebih mengutamakan kualitas diri dari pada menikah di usia yang masih sangat dini. 


\section{DAFTAR PUSTAKA}

A. Yunus. (2020). Hukum Perkawinan dan Itsbat Nikah: Antara Perlindungan dan Kepastian Hukum. humanities genius.

Admin, (2014), "Contoh Proposal Metode Penelitian Hukum - Aspek Yuridis Pemilihan Anggota Badan Perwakilan Desa", (Online), (https://www.contoh-proposal-metodepenelitian-hukum-aspek-yuridis-pemilihan-anggota-badan-perwakilan-desa.html) diakses pada 20 Maret 2021.

Badan Pusat Statistik. (2019). “Persentase Perempuan Jawa Timur Usia 10 Tahun ke Atas yang Kawin di Bawah Umur (Kurang dari 17 Tahun) menurut Kabupaten/Kota (Persen)". (Online), (https://jatim.bps.go.id/indicator/12/487/1/persentaseperempuan-jawa-timur-usia-10-tahun-ke-atas-yang-kawin-di-bawah-umur-kurangdari-17-tahun-menurut-kabupaten-kota.html) diakses pada 22 April 2021

Dian Ety Mayasari; Andreas L. Atjengbharata. (2020). "Pengaturan Batas Usia untuk Melakukan Perkawinan Ditinjau dari Undang-Undang Perlindungan Anak." DiH: Jurnal Ilmu Hukum. Volume 16 Nomor 2. Agustus 2020.

J.A. Aldi, E.P. Tanbun, \& X. Nugraha. (2019). “Tinjauan Yuridis Kewenangan Dewan Kehormatan Penyelenggara Pemilu (DKPP) dalam Menciptakan Pemilu yang Demokratis di Indonesia". Jurnal Hukum De'rechtsstaat, Volume 5 Nomor 2.

Maidin Gultom. (2014). Perlindungan Hukum terhadap Anak dan Perempuan. Bandung: Refika Aditama.

Moh. Zahid. (2002). "Dua Puluh Lima Tahun Pelaksanaan Undang-Undang Perkawinan”, Departemen Agama RI Badan Litbang Agama dan Diklat Keagamaan

PERMA RI Nomor 5 Tahun 2019 Tentang Pedoman Mengadili Permohonan Dispensasi Kawin

Permatasari, Erizka, (2021). "Hukumnya Menikah di Usia Dini". (Online), (https://m.hukumonline.com/klinik/detail/ulasan/lt5b8f402eed78d/hukumnyamenikah-di-usia-dini/) diakses pada 21 Juni 2021.

Ramadhita. (2014). "Diskresi Hukum : Pola Penyelesaian Kasus Dispensasi Perkawinan”, De Jure Jurnal Syariah dan Hukum, Fakultas Syariah UIN Maulana Malik Ibrahim Malang, Volume 6. Nomor 1.

Salinan Putusan Mahkamah Konstitusi Republik Indonesia Nomor 22/PUU-XV/2017

Soerjono Soekanto. (2016). Faktor-Faktor yang Mempengaruhi Penegakan Hukum. Depok: Raja Grafindo Persada.

Undang-Undang Dasar Negara Republik Indonesia Tahun 1945

Undang-Undang Perkawinan Nomor 16 Tahun 2019

Wawancara bersama Sekretaris Peradi Blitar, Muhamad Chairul, S.H. pada 28 Juli 2021

Wawancara bersama Bapak Tri Elyas Setyawan, S.H. pada 24 Agustus 2021

Wawancara bersama Hakim Pengadilan Agama Blitar Bapak Drs. H. Abu Syakur, M.H. pada Selasa, 10 Agustus 2021.

Wawancara bersama orang tua pelaku perkawinan dini, pada 23 Februari 2021.

Wawancara dengan Bapak Djauhari pada 21 Juli 2021.

Wawancara dengan Kepala KUA Kecamatan Garum Bapak Muh. Syihabuddin, M.Ag. pada Jum'at, 23 Juli 2021. 